\title{
RELATIONSHIP BETWEEN LEARNING INTENSITY, NUMERICAL SKILLS, AND EXTRACURRICULAR PARTICIPATION WITH MATHEMATICAL LEARNING OUTCOMES OF SMA NEGERI 1 PUNDONG
}

\author{
Lara Hikmatullaha, Uswatun Khasanah ${ }^{\mathrm{b}}$ \\ Program Studi Pendidikan Matematika Universitas Ahmad Dahlan \\ Jalan Ring Road Selatan, Tamanan, Banguntapan, Bantul Yogyakarta

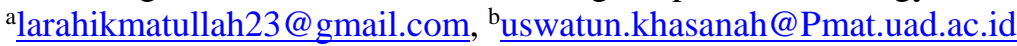

\begin{abstract}
Low student learning outcomes are related to many factors. Learning intensity, numerical ability, and extracurricular participation are several factors related to learning outcomes. This study aims to determine the presence or absence of a positive and significant relationship between learning intensity, numerical ability, and extracurricular participation with mathematics learning outcomes of class X students in the even semester of SMA Negeri 1 Pundong, Bantul Regency in the academic year 2015/2016. SMA Negeri 1 Pundong, Bantul Regency in the 2015/2016 academic year consisted of 7 classes. Class X.1 has an average value of UAS higher than other classes so that the population in this study classes X.2 to X.7. The sampling technique uses random sampling and X.6 is chosen as the sample class. Data collection techniques using questionnaires, tests, and documentation. Data collection instruments using a list of documents, learning intensity questionnaire, numerical ability test, and learning achievement test. The research instrument test uses a validity test, reliability test, and different power test. Analysis prerequisite tests include normality test, linearity test, and independence test. Data analysis for hypothesis testing uses product-moment correlation analysis and multiple linear regression analysis. The results showed that there was a positive and significant relationship between learning intensity, numerical ability and extracurricular participation with mathematics learning outcomes. At a significant level of $5 \%, v_{1}=3, v_{2}=23, F_{\text {count }}=6,0145956099$ and $F_{\text {table }}=3,027998, F_{\text {count }}>$ $F_{\text {table }}$ with a double correlation coefficient $\mathrm{R}=0.663$ and a triple regression equation, that is $\hat{Y}=$ $1,142652+0,750181 X_{1}+0,102868 X_{2}+13,828041 X_{3}$. Relative contribution $X_{1}=23,438 \%$, $X_{2}=9,462 \%, X_{3}=48,149 \%$, with a double determination coefficient of 0.439 and its effective contribution $X_{1}=18,635 \%, X_{2}=4,160 \%$ dan $X_{3}=21,168 \%$.
\end{abstract}

Keywords: Learning Intensity, Numerical Ability, Extracurricular Participation, Learning Outcomes

\section{INTRODUCTION}

Education is an important factor in a person's life. To prepare quality human resources, the government of the Republic of Indonesia has given considerable attention to the world of education by trying hard to improve the quality of national education. This is evident in the national education objectives stated in Law No. 20 of 2003 article 3 concerning the National Education System.

Mathematics is a basic science that must be mastered in developing science and technology. Some students have difficulty understanding the material given by the teacher during class lessons which results in students disliking mathematics because they consider mathematics a difficult and boring subject, and even a tendency appears that mathematics is increasingly developed into a scary subject. Therefore, it is not impossible for student mathematics learning outcomes tend to be less than the maximum. This can be seen from the value of the Final Test of the Odd Semester (UAS) of SMA 1 Pundong, Bantul Regency in mathematics in the 2015/2016 academic year which is still below the Minimum Mastery Criteria (KKM) set by the school. In learning mathematics, understanding concepts and lots of practice are needed, because in mathematics the most attention is not the end result but the process of getting results. Learning mathematics is not only enough once or twice but students must learn it repeatedly or as often as possible. Therefore, the intensity of learning is needed to get optimal learning results. Learning intensity is a state of the seriousness of students in student efforts continuously, especially in learning mathematics. According to Nuzurah in Amelia (2014: 7) indicators of student learning intensity are the duration of activities, the frequency of activities, presentations, direction of attitude, interests, and activities. Studying mathematics is different from other lessons that 
can be learned only by memorization. Therefore we need the ability to count (numerical) in solving mathematical problems. The number of teaching aids such as calculators and computers now has an effect on students' numerical ability. This can be seen from the majority of students who have low test results in their basic calculations because the mental activities of students in counting are replaced by pressing calculator and computer symbols. So that at the time of the test or exam students have difficulty because they are not allowed to bring the calculator into the room. In addition, students in schools not only attend learning activities, but students are also active in extracurricular activities. Extracurricular activities can channel the talents and interests of students, but many students are not able to divide their time well so that they often do not enter class and lag behind learning material. Extracurricular participation is mental and emotional involvement as well as the physical involvement of students in extracurricular activities to channel students' interests, talents, hobbies, personalities, and creativity and develop thinking intelligence.

SMA Negeri 1 Pundong is one of the high schools that has a variety of extracurricular activities that are in high demand by students, including Volleyball, Basketball, Silat, Karate, Music, Dance, Choir, PMR, UKS, KIR, PIK, Sewing, Tonti Board, English Club and Scouts (required). The extracurricular activities have a fixed schedule every week, so students are expected to be able to choose extracurricular activities that are in accordance with their talents and interests and do not interfere with their learning activities. The high interest of students in participating in extracurricular activities so that most students are involved in extracurricular activities. However, there are also students who are not interested in or not participating in extracurricular activities on the grounds that parents are prohibited and cannot divide their time for fear of influencing their learning outcomes.

Learning outcomes are the results of the learning process, namely the level of mastery achieved by students in participating in teaching and learning activities with established educational goals. Low learning outcomes may be due to a lack of intensity in learning mathematics, the weak numerical ability of students and student participation in extracurricular activities.

Based on the background and boundaries of the problem, it can be formulated the problem to be investigated, is there a positive and significant relationship between learning intensity, numerical ability and extracurricular participation with mathematics learning outcomes of class $\mathrm{X}$ students in the even semester of SMA Negeri 1 Pundong in the 2015/2016 school year?

The aim of this study is to find out whether there is a positive and significant relationship between learning intensity, numerical ability and extracurricular participation with mathematics learning outcomes of class X students in the even semester of SMA Negeri 1 Pundong in the 2015/2016 school year.

\section{METHODS}

This research is classified as quantitative research. The place of research was conducted at SMA Negeri 1 Pundong. While the time of the study was conducted in the even semester of the academic year 2015/2016. The population in this study were students of class X in the even semester of SMA Negeri 1 Pundong consisting of 7 classes. Based on the average value of UAS class X.1 has an average that is much higher than other classes so that the population in this study consisted of 6 classes. While the sample in this study is class X.6 and class X.7 as a test class. The sampling technique used is Random Sampling. The research variables are two variables, they are the independent variable and the dependent variable. The independent variable (Independent) consists of learning intensity ( $\left.\mathrm{X}_{1}\right)$, numerical ability $\left(\mathrm{X}_{2}\right)$ and extracurricular participation $\left(\mathrm{X}_{3}\right)$, while the dependent variable (dependent) is the result of learning mathematics (Y).

In this study, Extracurricular participation variables are also dummy variables. Dummy variables are variables that are used to quantify qualitative variables. This research regression model is a combination of quantitative and dummy variables. In this study, students were divided into two large groups. The first group is a group of students who take extracurricular activities (1). While the second group is a group of students who do not join extracurricular activities (0). Data collection techniques 
using questionnaires, tests, and documentation. Data collection instruments used a list of documents, a questionnaire method to obtain data on learning intensity, and a test method to obtain data on numerical abilities and mathematics learning outcomes of class X students at SMA Negeri 1 Pundong. While the documentation to obtain data on students who take extracurricular activities in class X students at SMA Negeri 1 Pundong. The questionnaire test uses the content validity test by the reviewers and the instrument reliability test using the alpha formula, while the test instrument questions use the instrument validity test with product-moment correlation techniques, different power tests and instrument reliability test with the KR-20 formula (Suharsimi Arikunto. 2009: 100 ). After the data is collected, the analysis prerequisite tests that must be met include normality test, linearity test, and independence test. Data analysis uses product-moment correlation analysis and multiple linear regression analysis.

\section{RESULTS AND DISCUSSION}

In this section further discussion of the results of research analyzed in correlation. This study found that the seventh hypothesis test results were a positive and significant relationship between learning intensity, numerical ability and extracurricular participation with mathematics learning outcomes. In other words, the better the intensity of student learning, the better the learning outcomes. Likewise with numerical ability, the higher the numerical ability, the higher the learning outcomes. In addition, extracurricular participation also influences learning outcomes. In this study also uses analysis prerequisite tests which include:

\section{Test for normality}

This normality test is used to test the distribution of data obtained by each variable whether it is normally distributed or not. The summary of the normality test results from the four variables are:

Table 1. Summary of Normality Test Results

\begin{tabular}{|c|l|c|c|c|c|}
\hline No & \multicolumn{1}{|c|}{ Variable } & $\chi_{\text {count }}^{\mathbf{2}}$ & $\boldsymbol{\chi}_{\text {table }}$ & Df & Info \\
\hline 1 & Intensitas Belajar $\left(X_{1}\right)$ & 3,73 & 5,991 & 2 & Normal \\
\hline 2 & $\begin{array}{l}\text { Kemampuan Numerik } \\
\left(X_{2}\right)\end{array}$ & 3,0504 & 7,815 & 3 & Normal \\
\hline 3 & $\begin{array}{l}\text { Hasil Belajar } \\
\text { Matematika }(Y)\end{array}$ & 5,3574 & 7,815 & 2 & Normal \\
\hline
\end{tabular}

\section{Independence test}

Independence test is used to find out whether or not there is a relationship between independent variables. A summary of the results of the independent tests of the three independent variables is:

Table 2. Summary of Independence Test Results

\begin{tabular}{|c|c|c|c|c|c|}
\hline No & Variable & $\boldsymbol{\chi}_{\text {count }}^{\mathbf{2}}$ & $\boldsymbol{\chi}_{\text {table }}^{\mathbf{2}}$ & Df & Info. \\
\hline 1 & $X_{1}$ against $X_{2}$ & 229,092 & 437,652 & 25 & Independent \\
\hline 2 & $X_{1}$ against $X_{3}$ & 66,5250 & 411,0705 & 5 & Independent \\
\hline 3 & $X_{2}$ against $X_{3}$ & 9,7016 & 111,0705 & 5 & Independent \\
\hline
\end{tabular}

\section{Linearity Test}

Linearity test is used to find out between independent variables and dependent variables whether they have a linear relationship or not. Summary of the linearity test results of the four variables are:

Table 3. Summary of Linearity Test Results

\begin{tabular}{|c|c|c|c|c|}
\hline No & Variable & $\boldsymbol{F}_{\text {count }}$ & $\boldsymbol{F}_{\text {table }}$ & Info. \\
\hline 1 & $X_{1}$ againts $Y$ & 1,5835 & 2,74 & Linear \\
\hline 2 & $X_{2}$ againts $Y$ & 1,86034 & 2,54 & Linear \\
\hline
\end{tabular}




\section{Hypothesis testing}

From the multiple correlation analysis, the value of the multiple correlation coefficient $(R)$ is 0.663 . In this study also obtained a coefficient of determination $\left(\mathrm{R}^{2}\right)$ of 0.439 meaning that the variance of mathematics learning outcomes $(\mathrm{Y})$ can be explained by the intensity of learning $\left(\mathrm{X}_{1}\right)$, numerical ability $\left(\mathrm{X}_{2}\right)$, and extracurricular participation $\left(\mathrm{X}_{3}\right)$ through linear lines $\hat{Y}=1,143+0,750 X_{1}+$ $0,103 X_{2}+13,828 X_{3}$. This means that every increase of one unit $X_{1}$ results in a 0.750181 increase in $\mathrm{Y}$, an increase in one unit $\mathrm{X}_{2}$ results in a 0.102868 increase in $\mathrm{Y}$ and an increase in one unit $\mathrm{X}_{3}$ results in 13.828041 increase in $\mathrm{Y}$.

a. The equation for students who take extracurricular activity, $\mathrm{X}_{3}=1$, so that:

$$
\begin{array}{ll}
\hat{Y}=1,142652+0,750181 \mathrm{X}_{1}+ & 0,102868 \mathrm{X}_{2}+13,828041 \mathrm{X}_{3} \\
\hat{Y}=1,142652+0,750181 \mathrm{X}_{1}+ & 0,102868 \mathrm{X}_{2}+13,828041(1) \\
\hat{Y}=14,970693+0,750181 \mathrm{X}_{1}+ & 0,102868 \mathrm{X}_{2}
\end{array}
$$

b. The equation for students who do not take extracurricular activities, $X_{3}=0$, so that:

$$
\begin{array}{ll}
\hat{Y}=1,142652+0,750181 \mathrm{X}_{1}+ & 0,102868 \mathrm{X}_{2}+13,828041 \mathrm{X}_{3} \\
\hat{Y}=1,142652+0,750181 \mathrm{X}_{1}+ & 0,102868 \mathrm{X}_{2}+13,828041(0) \\
\widehat{Y}=1,142652+0,750181 \mathrm{X}_{1}+ & 0,102868 \mathrm{X}_{2}
\end{array}
$$

From the above equation, the coefficient for the extracurricular participation variable shows a positive number that is 13.828041 which means that students who take extracurricular activities have an average of 13.828041 compared to students who do not participate in extracurricular activities. So that the prediction of learning outcomes in terms of learning intensity and numerical ability, students who take extracurricular activities are higher than students who do not take extracurricular activities.

As for the relative contribution of $X_{1}$ by $23.438 \%, X_{2}$ by $9.462 \%$ and $X_{3}$ by $48.149 \%$ and the effective contribution of $\mathrm{X}_{1}$ by $18.635 \%, \mathrm{X}_{2}$ by $4.160 \%$ and $\mathrm{X}_{3}$ by $21.168 \%$. This shows that the intensity of learning provides a more significant relationship with mathematics learning outcomes compared to numerical ability and extracurricular participation.

\section{CONCLUSION}

Based on the results of research and discussion as described above, it can be concluded that there is a positive and significant relationship between learning intensity, numerical ability and extracurricular participation with mathematics learning outcomes of class $\mathrm{X}$ students in the even semester of SMA Negeri 1 Pundong 2015/2016 academic year. This is indicated by the F-test that is $F_{\text {count }}>F_{\text {table }}$ or $6,014595>3,027998$ with a multiple correlation coefficient $(\mathrm{R})$ of 0.663 and a coefficient of determination $\left(\mathrm{R}^{2}\right)$ of 0.439 . Linear regression equation $\hat{Y}=1,142652+$ $0,750181 X_{1}+0,102868 X_{2}+13,828041 X_{3}$. The relative contribution of $X_{1}$ was $23.438 \%, X_{2}$ was $9.462 \%$ and $X_{3}$ was $48.149 \%$ and the effective contribution was $18.635 \%, X_{2}$ was $4.160 \%$ and $X_{3}$ was $21.168 \%$.

\section{REFERENCES}

Arikunto,Suharsimi.2010. Prosedur Penelitian (Suatu Pendekatan Praktik).Jakarta:Rineka Cipta. 2012.Dasar-Dasar Evaluasi Pendidikan.Jakarta:Bumi Aksara.

Davis Keith, John W. 1992. Newstrom. Perilaku Dalam Organisasi. Jakarta:Erlangga.

Djamarah, Syaiful Bahri.2011.Psikologi Belajar.Jakarta:Rineka Cipta.

Fudyartanta, Ki.2010. Test bakat dan perskalaan kecerdasaan. Yogyakarta: Pustaka Pelajar

Hadi, S. 2004. Analisis Regresi. Yogyakarta: Andi.

Hamalik, O. 1992.Psikologi Belajar dan Mengajar.Bandung:Sinar Baru.

Hudojo, Herman. 1979. Mengajar Belajar Matematika. Jakarta:PT.Rineka Cipta.

Makmun, Abin Syamsudin.2009. Psikologi Kependidikan (Perangkat Sistem Pengajaran Modul).Bandung : PT. Remaja Rosdakarya. 
Naga, Dali S.(1980). Berhitung Sejarah Dan Pengembangannya. Jakarta: PT Gramedia.

Purwanto.2013.Evaluasi Hasil Belajar.Yogyakarta: Pustaka Pelajar.

Slameto.2013. Belajar dan Faktor-Faktor yang Mempengaruhi. Jakarta:Rineka Cipta.

Sudjana, N. 2015. Penilaian Hasil Proses Belajar Mengajar. Bandung: PT. Remaja Rosdakarya, cetakan kedelapanbelas.

.2005.Metode Statistika.Bandung: Alfabeta

Sugiyono.2015.Metode Penelitian Pendidikan (Pendekatan Kuantitatif, Kualitatif, dan $R$ \& $D$ ).Bandung: Alfabeta.

2005. Statistika Untuk Penelitian. Bandung:Alfabeta.

Suherman, Erman dkk.2003. Common Texs Book (Edisi Revisi) Strategi Pembelajaran Matematika Kontemporer. Bandung: Fakultas Pendidikan Matematika dan Ilmu Pengetahuan Alam UPI JICA.

Sukardjono. 2007.Filsafat dan Sejarah Matematika.Jakarta: Universitas Terbuka. 